\title{
How Exercise May Affect The Immune System Against COVID-19?
}

\section{Egzersiz COVID-19'a Karşı Bağışıklık Sistemini Nasıl Etkileyebilir?}

\author{
Mustafa Turgut Yıldızgören \\ Physical Medicine and Rehabilitation Clinic, Fizikon Medical Center, Konya, Türkiye
}

The severe acute respiratory coronavirus syndrome (SARS-CoV-2) infection causing coronavirus disease 2019 (COVID-19) emerged in Wuhan, China in December 2019 and spread rapidly from China throughout the whole World (1). At the time of writing, more than 3,4 million people around the world have been infected with more than 239,000 deaths. There are currently 122,000 confirmed cases of coronavirus and 3,200 deaths in Turkey as of 2 May 2020. It seems that the number of cases in the near future will continue to rise.

COVID-19 symptoms are non-specific and presentation of the disease can range from asymptomatic to severe pneumonia or acute respiratory distress syndrome and death. Although the majority of COVID-19 patients have mild clinical symptoms, a subset of more severely infected patients experience pulmonary involvement and multi-organ failure (2). Together with the "personal hygiene", "social isolation" and "low contact" measures which are brought with the instructions to "stay at home", it is possible to protect against infection or reduce the effects of the disease with a strong

M. T. Ylldızgören (iD 0000-0002-9697-6184

Geliş Tarihi/Date Received: 02.05.2020

Kabul Tarihi/Date Accepted: 05.05.2020

Yayın Tarihi/Published Online: 07.05.2020

Yazışma Adresi /

Corresponding Author:

Mustafa Turgut Yıldızgören

Fizikon Tip Merkezi, Fiziksel

Tıp ve Rehabilitasyon Kliniği,

Konya, Türkiye

E-mail:

ftr.mustafaturgut@hotmail.com

(C)2020 Türkiye Spor Hekimleri Derneği. Tüm hakları saklıdır. immune system. There are well-known beneficial effects of adequate sleep, stopping smoking, a balanced diet, and reducing stress levels to strengthen the immune system.

The effect of exercise on the immune system may vary. Moderate intensity exercise appears to have a protective effect, whereas overtraining, high intensity and prolonged strenuous exercises can result in immune dysfunction. The main question in the field of physiatry in the current shadow of the pandemic is how exercise may affect the immune system to protect against coronavirus. Recent studies have shown that physical exercise of moderate intensity has beneficial effects on immune system responses to viral respiratory infections. Elevated neutrophil and natural killer (NK) cell counts have been observed after moderate level physical activity and IgA concentration in the saliva has also been reported to be increased. Moderate intensity physical activity increases stress hormones, resulting in a decrease in excessive inflammation. This in turn enhances immunity against viral infections through changes in Th1/Th2 cell responses. In individuals with regular moderate physical activity as a part of daily life, upper respiratory tract infections have been recorded at 
levels of $20-30 \%$ lower than those who have a sedentary lifestyle (3). However, prolonged strenuous exercises leads to immunsupression. Following severe exercise, reduction in lymphocyte counts, cell proliferation and antibody production have been detected. There is an "open window" period of 3-72 hours following strenuous exercise, when immunity is weakened and micro-organisms, especially viruses can enter the body and cause infections (4). Thus, for those who are staying at home during the coronavirus pandemic, exercise should be of moderate intensity that will not cause stress. There has been shown to be a Jshaped correlation between physical activity and respiratory tract infection (4). (Figure 1) Physical activity of a moderate intensity is known to boost the immune system with a reduced risk of respiratory tract viral infections.

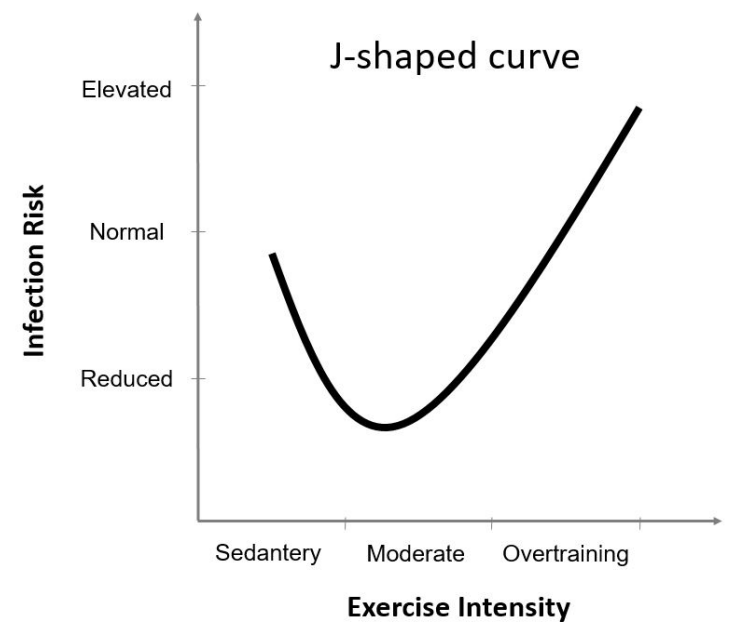

Figure 1. J-shaped curve showing relationship between exercise intensity and infection risk.

Due to the high contagion risk as previously mentioned from infected individuals or contaminated surfaces, it is much more appropriate to exercise at home with personal equipment in a well-ventilated room. A home exercise program can be designed to include a combination of walking, strengthening, stretching and balance exercises. When possible, moderate intensity aerobic exercise, such as brisk walking outdoors is a good alternative if safe distancing can be maintained. As high intensity exercise in sports hall and crowded places has more risks than benefits, it should be avoided. It is important that a balanced diet is maintained with the intake of vitamin rich nutrients and fluid prior to exercise.

In conclusion, in the efforts to protect community health, immobility and sedentary lifestyle should be prevented, since strong immune system plays an important role in asymptomatic patients, possibly preventing COVID-19. Better functioning of the immune system can be achieved with a good balanced diet, rich in vitamins and trace elements, sufficient sleep, regular exercise with moderate intensity, keeping stress levels under control and stopping smoking.

Available at: http://journalofsportsmedicine.org and http://dx.doi.org/10.5152/tjsm.2020.189

Cite this article as: Yildizgoren MT. How exercise may affect the immune system against COVID-19? Turk $J$ Sports Med. 2020;55(2):186-7.

\section{Conflict of Interest}

The authors declared no conflicts of interest with respect to the authorship and/or publication of this article.

\section{REFERENCES}

1. Wang C, Horby PW, Hayden FG, Gao GF. A novel coronavirus outbreak of global health concern [published correction appears in Lancet. 2020 Jan 29]. Lancet. 2020;395:470-3.

2. Thomas-Rüddel D, Winning J, Dickmann P, Ouart D, Kortgen A, Janssens U, et al. Coronavirus disease 2019 (COVID-19): update for anesthesiologists and intensivists. Anaesthesist. 2020;69:225-35.

3. Martin SA, Pence BD, Woods JA. Exercise and respiratory tract viral infections. Exerc Sport Sci Rev. 2009;37:157-64.

4. Ahmadinejad Z, Alijani N, Mansori S, Ziaee V. Common sportsrelated infections: a review on clinical pictures, management and time to return to sports. Asian J Sports Med. 2014;5:1-9. 